\title{
PERBANDINGAN STRUKTUR FUNGSIONAL CERITA RAKYAT SUMATERA BARAT DAN KALIMANTAN SELATAN: LEGENDA ANAK DURHAKA
}

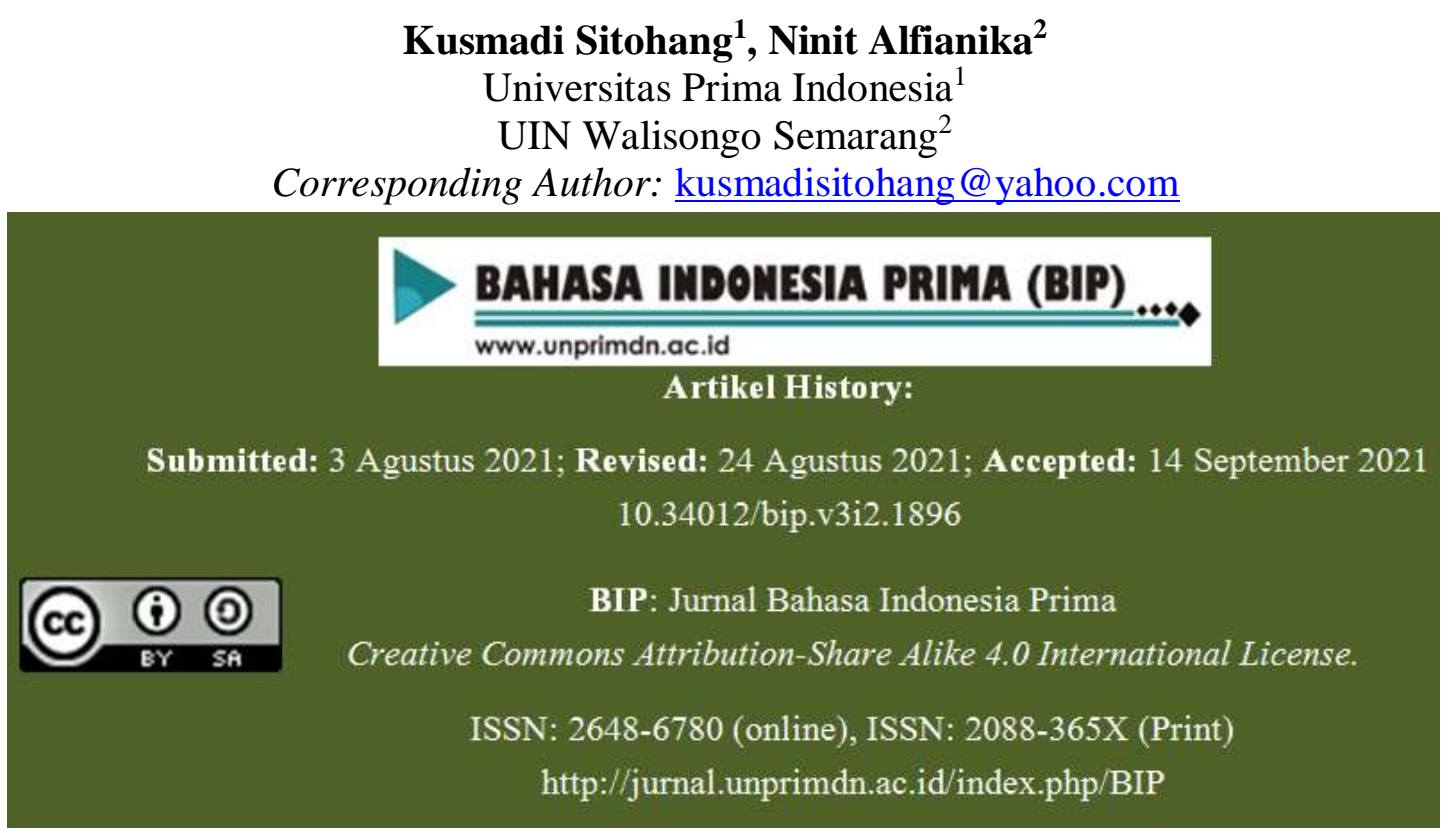

Abstrak-Tujuan penelitian ini mendeskripsikan perbandingan struktur fungsional cerita rakyat Sumatera Barat berjudul Malin Kundang dan cerita rakyat Kalimantan Selatan berjudul Gunung Batu Bangkai. Cerita ini, sama-sama bertemakan anak durhaka. Jenis penelitian kualitatif dengan menggunakan metode perbandingan. Data penelitian, yaitu kalimat berkaitan dengan struktur fungsional yang terdapat dalam kedua cerita rakyat tersebut. Sumber data penelitian ini, cerita rakyat dari Sumatera Barat berjudul Malin Kundang dan dari Kalimantan Selatan berjudul Gunung Batu Bangkai dalam bentuk tulisan. Kedua cerita rakyat ini, dianalisis menggunakan teori struktural fungsional Greimas. Hasil penelitian menunjukkan secara struktur fungsional, perbandingan kedua cerita rakyat dilihat dari situasi awal, transformasi, dan situasi akhir. Persamaan situasi awal kedua cerita rakyat tersebut, yaitu tokoh utama sama-sama berkeinginan merantau. Perbedaan dilihat dari jumlah tokoh dan bekal merantau yang diberikan. Persamaan transformasi kedua cerita rakyat tersebut, yaitu tokoh utama sama-sama berangkat merantau; hidup bahagia dan istri cantik; menjadi anak durhaka. Perbedaannya dilihat dari alat digunakan untuk merantau; peristiwa yang dialami diperjalanan; usaha yang dilakukan mencapai kesuksesan. Persamaan situasi akhir kedua cerita rakyat tersebut yaitu, sama-sama berubah menjadi batu. Perbedaannya, dilihat dari proses tokoh utama menjadi batu, bentuk, dan letak batunya. Jadi, dapat disimpulkan dilihat dari struktur fungsional kedua cerita rakyat tersebut memiliki persamaan dan perbedaan.

Kata kunci: perbandingan, struktur fungsional, cerita rakyat

Abstract-The purpose of this study is to describe a comparison of the functional structure of West Sumatra folklore entitled MalinKundang and South Kalimantan folklore entitled BatuBangkai Mountain. This story, together with the theme of ungodly children. Type of 
qualitative research using the comparison method. Research data, namely sentences related to functional structures contained in both folklore. The source of this research data, West Sumatra folklore entitled MalinKundang and from South Kalimantan entitled GunungBangkai in written form. These two folktales are analyzed using Greimas' functional structural theory. The results of the study show functional structure, the comparison of the two folktales seen from the initial situation, transformation, and the final situation. The similarity of the initial situation of the two folktales, namely the main character both wish to migrate. The difference is seen from the number of figures and provision of wanderings given. The equation of the second transformation of the folklore, namely the main character both departed wander; happy life and beautiful wife; being a rebellious child. The difference is seen from the tools used to migrate; events experienced on the way; the effort made achieved success. Persamaa the second situation of the folklore, namely, both turned into stone. The difference, seen from the process of the main character being stone, shape, and location of the stone. So, it can be concluded that the functional structure of the two folklore has similarities and differences.

Keywords: comparison, functional structure, folklore

\section{A. Pendahuluan}

Cerita rakyat merupakan salah satu bentuk kekayaan Indonesia di bidang kesusasteraan. Tidak ada daerah di Indonesia yang tidak memiliki cerita rakyat. Cerita rakyat merupakan salah satu bentuk ekspresi kebudayaan daerah yang jumlahnya beratus-ratus di seluruh Indonesia. Bahasa-bahasa daerah yang menjadi media pengucapan cerita rakyat itu juga merupakan bagian dari kebudayaan tradisional, yaitu bahasa yang paling tepat dapat mengekspresikan isi kebudayaan daerah yang bersangkutan (Rosidi, 1995).

Pada awalnya cerita rakyat adalah salah satu tradisi lisan yang disampaikan secara turut temurun di dalam masyarakat. Sastra lisan adalah kesusastraan yang mencakup ekspresi kesusastraan warga dalam suatu kebudayaan yang disebarkan turun-temurun secara lisan, dengan ciriciri, yaitu disebarkan dari mulut kemulut; lahir di masyarakat yang bercorak tradisional; menggambarkan ciri-ciri budaya suatu masyarakat; memiliki berbagai versi; menggunakan gaya bahasa lisan (sehari-hari), (Danandjaya, 1997). Bascom (dalam Danandjaya, 1997) menjelaskan bahwa cerita rakyat dapat dibagi dalam tiga golongan besar, yaitu mite, legenda, dan dongeng.

Salah satu jenis cerita rakyat adalah legenda. Legenda adalah cerita prosa kisah sejarah, dongeng, hikayat, atau tambo rakyat yang dianggap sebagai suatu kejadian yang sungguh-sungguh pernah terjadi, (Danandjaya, 1997 dan Endarmoko, 2006). Cerita rakyat yang berupa legenda diyakini masyarakat sekitar sebagai cerita yang benar-benar terjadi. Contohnya saja legenda Malin Kundang dari Sumatera Barat dan Legenda Gunung Batu Bangkai dari Kalimantan Selatan. Kedua cerita rakyat tersebut, diyakini kebenarannya karena ada buktinya nyata dari peninggalan kedua cerita rakyat tersebut dalam bentuk batu.

Kedua cerita rakyat ini awalnya berasal dari tradisi lisan, yang berupa sastra lisan yang tergolong legenda. Biasanya sastra lisan, hanya bisa dinikmati dalam bentuk lisan dan penyampainnya dari mulut kemulut. Namun, dengan perkembangan 
teknologi cerita rakyat tidak hanya disajikan dalam bentuk lisan, tetapi bisa dituangkan dalam bentuk tulisan yang disertai dengan gambar yang menarik, (Kartika, 2018). Begitu juga dengan cerita rakyat Malin Kundang dari Sumatera Barat dan Gunung Batu Bangkai dari Kalimantan Selatan. Kedua cerita itu, sudah dapat dinikmati dalam bentuk tulisan.

Selain sama-sama cerita rakyat berbentuk legenda, kedua cerita ini juga memiliki motif yang sama, yaitu samasama menceritakan anak durhaka kepada ibunya. Akibat kedurhakaan itu, kedunya sama-sama diazab oleh Allah menjadi batu. Dalam cerita rakyat kesamaan motif merupakan hal yang biasa karena adanya pembuat cerita yang aktif. Bagi ahli folklor adanya persamaan pada kesatuan-kesatuan cerita (tale types) atau unsur-unsur kesatuan cerita (tale motifs) dalam cerita rakyat di berbagai suku bangsa di Indonesia bukanlah suatu hal yang aneh. Teori itu tergolong monogenesis dan poligenesis. Monogenesis adalah terjadinya persamaan disebabkan oleh penyebaran dari suatu kesatuan cerita (plot) atau motif cerita dari satu tempat ke tempat-tempat lain. Poligenesis menganggap bahwa terjadinya persamaan disebabkan oleh penemuan sendiri-sendiri (independent invention) atau sejajar (paralel invention), (Danandjaya, 2007).

Dengan adanya kesamaan motif, kedua cerita rakyat tersebut dapat dianalisis dengan menggunakan pendekatan sastra bandingan. Hal itu, sesuai dengan yang dikemukakan oleh Jost 1974 (dalam Damono, 2009) bahwa pendekatan dalam sastra bandingan dapat dibagi menjadi empat, yaitu pengaruh dan analogi; gerakan dan kecendurungan; gendre dan bentuk; motif, tipe, dan tema. Oleh sebab itu, cerita rakyat yang memiliki motif dan tema yang sama bisa dianalisis meggunakan kajian sastra bandingan.

Berdasarkan hal tersebut, maka dilakukan penelitian yang berkaitan dengan sastra bandingan.Cerita rakyat yang ingin di bandingkan adalah cerita rakyat dari provinsi Sumatera Barat yang berjudul Malin Kundang dan cerita rakyat dari Provinsi Kalimantan Selatan yang berjudul Gunung Batu Bangkai. Alasan dibandingkan kedua cerita rakyat ini adalah cerita rakyat ini memiliki motif yang sama, yaitu sama-sama menceritakan tentang anak durhaka yang azab Allah menjadi batu. Selain itu, kedua cerita rakyat ini berasal dari provinsi yang berbeda, sehingga bisa dilakukan kajian bandingan.

Sastra bandingan adalah pendekatan dalam ilmu sastra yang tidak menghasilkan teori tertentu, (Damono, 2009). Teori yang digunakan untuk membandingkan cerita rakyat dari provinsi Sumatera Barat yang berjudul Malin Kundang dan cerita rakyat dari Provinsi Kalimantan Selatan yang berjudul Gunung Batu Bangkai adalah struktur fungsional. Untuk memahami sebuah karya sastra harus dilakukan analisis terhadap struktur karya sastra tersebut. Karya sastra terdiri dari struktur yang kompleks, analisis struktur dilakukan untuk memahami sebuah cerita, (Hill dalam Pradopo, 1995)

Analisis struktur fungsional yang digunakan untuk menganalisis kedua cerita rakyat tersebut merujuk pada teori struktural fungsional yang dikemukakan oleh Greimas. Greimas (dalam Mustafa, 2017) menjelaskan bahwa struktur fungsional dalam sebuah cerita dapat dibagi menjadi tiga tahap, yaitu (1) situasi awal; (2) transformasi yang meliputi tahap kecakapan, tahap utama, dan tahap 
kegemilangan; (3) situasi akhir. Lebih lanjut Greimas menjelaskan bahwa situasi awal dalam cerita rakyat dapat dilihat dari munculnya keinginan untuk mendapatkan sesuatu; adanya panggilan; adanya persetujuaan. Tahap transformasional uji kecapakan dapat dilihat dari keberangkatan tokoh utama (subjek) dari tanah asal; munculnya dewa penolong; adanya lawan tanding sang tokoh. Tahap transformasional bagian tahap awal dapat dilihat dari tokoh melewati masa perjuangan dengan segala tantangan. Tahap transformasional bagian tahap kegemilangan dapat dilihat dari masa kegemilangan tokoh dan sekaligus terbongkarnya jati diri tokoh yang sebenarnya. Situasi akhir dapat dilihat dari objek cerita akan memperoleh hukuman, balasan perbuatan yang telah dilakukan.

Berdasarkan teori, struktur fungsional Greimas tersebut, maka tujuan penelitian ini adalah mendeskripsikan perbandingan struktur fungsional cerita rakyat Sumatera Barat berjudul Malin Kundang dan cerita rakyat dari Kalimantan Selatan berjudul Gunung Batu Bangkai. Kedua cerita rakyat ini, dianalisis menggunakan teori struktural fungsional yang dikemukakan oleh Greimas.

\section{B. Metode Penelitian}

Jenis penelitian ini adalah penelitian kualitatif dengan menggunakan metode deskriptif bandingan. Menurut Moleong (1988), penelitian kualitatif adalah penelitian yang bermaksud untuk memahami fenomena tentang apa yang dialami oleh subjek penelitian, misalnya perilaku, persepsi, motivasi, secara holistik dan dengan cara deskripsi dalam bentuk kata-kata dan bahasa, pada suatu konteks khususnya yang alami dan dengan memanfaatkan berbagai metode ilmiah. Metode deskripsi bandingan digunakan untuk melihat, mendeskripsikan, menganalisis, dan membandingkan data yang berkaitan dengan struktur fungsional cerita rakyat dari Sumatera Barat yang berjudul Malin Kundang dan cerita rakyat dari Kalimantan Selatan yang berjudul Gunung Batu Bangkai. Sumber data dalam penelitian ini adalah cerita rakyat Sumatera Barat berjudul Malin Kundang dan cerita rakyat dari Kalimantan Selatan berjudul Gunung Batu Bangkai dalam bentuk tulisan. Data dalam penelitian ini adalah kata-kata yang berkaitan dengan struktur fungsional teori Greimas yang terdapat dalam kedua cerita tersebut. Instrumen dalam penelitian ini adalah peneliti sendiri dan dibantu dengan format inventarisasi dan analisis data. Teori yang digunakan untuk menganalisis data adalah teori struktural fungsional yang dikemukakan oleh Greimas. Teknik pengumpulan data dilakukan dengan cara (1) mencari kedua cerita rakyat tersebut di internet dengan bantuan google. (2) membaca kedua cerita rakyat tersebut dan menandai kata atau kalimat yang berkaitan dengan struktur fungsional. (3) mencatat data yang diperoleh ke dalam format inventarisasi data. Tahap penganalisisan data sebagai berikut (1) mengidentifikasi data sesuai dengan konsep penelitian. (2) mengklasifikasi data berdasarkan teori yang menjadi acuan, yaitu teori struktural fungsional yang dikemukakan oleh Greimas . (3) menganalisis dan membandingkan data dengan cara membahas kata-kata yang berkaitan dengan penelitian. (4) menginterpretasikan data yang sudah dianalisis sesuai dengan teori yang digunakan, dan (5) menyimpulkan hasil penelitian dalam bentuk menulis laporan. 


\section{Hasil dan Pembahasan}

Pada bagian ini dijelaskan hasil dan pembahasan. Hasil dan pembahasan yang dijelaskan berkaitan dengan struktur fungsional cerita rakyat dari Sumatera Barat yang berjudul Malin Kundang dan cerita rakyat dari Kalimantan Selatan yang berjudul Gunung Batu Bangkai. Analisis struktur fungsional kedua cerita rakyat tersebut merujuk pada teori yang digunakan Greimas. Greimas (dalam Mustafa, 2017) menyatakan bahwa struktur fungsional dibagi menjadi tiga tahap, yaitu situasi awal; transformasi yang meliputi tahap kecakapan, tahap utama, dan tahap kegemilangan; situasi akhir. Situasi awal berkaitan dengan munculnya keinginan untuk mendapatkan sesuatu; adanya panggilan; adanya persetujuaan. Tahap transformasional uji kecapakan berkaitan dengan keberangkatan tokoh utama (subjek) dari tanah asal; munculnya dewa penolong; adanya lawan tanding sang tokoh. Tahap transformasional bagian tahap awal berkaitan dengan tokoh melewati masa perjuangan dengan segala tantangan. Tahap transformasional bagian tahap kegemilangan ditandai dengan masa kegemilangan tokoh dan sekaligus terbongkarnya jati diri tokoh yang sebenarnya. Situasi akhir berkaitan dengan objek cerita akan memperoleh hukuman, balasan perbuatan yang telah dilakukan.

Struktur fungsional yag dijelaskan dalam penelitian ini, berkaitan dengan (1) struktur fungsional cerita rakyat dari Sumatera Barat yang berjudul Malin Kundang; (2) struktur fungsional cerita rakyat dari Kalimantan Selatan yang berjudul Gunung Batu Bangkai; (3) perbandingan struktur fungsional cerita rakyat dari Sumatera Barat yang berjudul Malin Kundang dan cerita rakyat dari
Kalimantan Selatan yang berjudul Gunung Batu Bangkai. Ketiga hal tersebut dijelaskan di bawah ini.

\section{Analisis Struktur Fungsional Cerita} Rakyat Sumatera Barat dengan Judul Malin Kundang

Pada bagian ini dijelaskan struktur fungsional cerita rakyat Sumatera Barat yang berjudul Malin Kundang. Struktur fungsional yang dijelaskan berkaitan dengan situasi awal, tahap transformasi yang terdiri dari tahap kecakapan, tahap utama, dan tahap kegemilangan, dan tahap akhir. Analisis itu merujuk pada teori yang dikemukan oleh Greimas bahwa struktur fungsional dibagi menjadi tiga tahap, yaitu situasi awal; transformasi terdiri dari tahap kecakapan, tahap utama, dan tahap kegemilangan; situasi akhir. Struktur fungsional cerita rakyat Sumatera Barat yang berjudul Malin Kundang, dijelaskan sebagai berikut.

Pertama, situasi awal dalam cerita rakyat Sumatera Barat yang berjudul Malin Kundang dimulai ketika Malin Kundang sebagai tokoh utama yang hanya hidup berdua dengan ibunya setelah sepeninggal ayahnya. Kehidupan yang miskin membuat Malin Kundang ingin merantau. Dia meminta izin kepada Ibunya yang bernama Mande Rubayah. Dengan berat hati Mande Rubayah mengizinkan Malin Kundang pergi merantau dan membekali Malin Kundang dengan sedikit uang dan tujuh bungkus nasi. Malin Kundang pergi merantau. Hal itu, dapat dibuktikan dengan kutipan berikut ini.

Tidak Bundo. Malin tidak akan pernah melupakan Bundo tercinta. Justru Malin ingin merantau agar bisa berhasil. Malin ingin Bundo bisa hidup berbahagia." jawab Malin Kundang. Malin merasa senang 
karena ibunya akhirnya mengizinkan

dirinya merantau, (Hlm. 2, P. 3).

Peristiwa tersebut dikatakan situasi awal karena menceritakan keinginan tokoh utama Malin Kundang, yaitu pergi merantau untuk memperbaiki hidup dan adanya persetujuan dari Mande Rubayah atas keinginan Malin Kundang tersebut. Hal itu sesuai dengan teori yang dikemukan oleh Greimas, bahwa situasi awal berkaitan dengan munculnya pernyataan keinginan untuk mendapatkan sesuatu; adanya panggilan; adanya persetujuaan.

Kedua, tahap transformasi terdiri dari tahap kecakapan, tahap utama, dan tahap kegemilangan. Pada tahap kecakapan, Malin Kundang pergi merantau. Malin Kundang pergi merantau menumpangi sebuah kapal yang berlabuh di kampungnya. Di dalam perjalanan, kapal yang ditumpangi Malin Kundang dihentikan oleh bajak laut. Malin Kundang selamat dari kejahatan itu. Malin Kundang terdapar di sebuah kampung, warga kampung menolongnya dan mengizinkan Malin Kundang menetap di kampung itu. Hal itu dapat dibuktikan dengan kutipan berikut ini.

Nahkoda kapal tersebut
mengizinkan Malin
menumpang kapalnya.Terima
kasih Nahkoda kapal yang
budiman.” jawab Malin, (Hlm.
2, P. 6).
Tidak disangka kejadian buruk
menimpa kapal tersebut. Bajak
Laut menyerang kapal dagang
tersebut, (Hlm. 3, P. 3).
Ia kemudian berjalan menuju
desa terdekat dari pantai
tersebut. Orang-orang di desa
tersebut segera menolong
Malin, (Hlm. 3, P. 4).

Peristiwa tersebut dikatakan tahap transformasi bagian kecakapan karena menceritakan tentang awal keberangkatan tokoh Malin Kundang pergi merantau, adanya musuh di jalan, dan masyarakat yang menolong Malin Kundang sebagai dewa penyelamat. Hal itu sesuai dengan teori yang dikemukan oleh Greimas, bahwa tahap kecakapan berkaitan dengan keberangkatan tokoh utama (subjek) dari tanah asal; munculnya dewa penolong; adanya lawan tanding sang tokoh.

Pada tahap utama, untuk mencapai kesuksesan, dimulai dari kerja serabutan dan dilanjutkan dengan berdagang. Karena kejujuran dan kerja kerasnya Malin Kundang sukses menjadi saudagar kaya raya. Kekayaan yang diperolehnya, membawa dia menikahi wanita yang paling cantik di desa tersebut. Hal itu dapat dibuktikan dengan kutipan berikut ini.

Malin kemudian berkerja serabutan di desa tersebut. Malin selalu teringat akan nasihat ibunya yang memintanya untuk bersikap jujur dan bekerja keras. Singkat cerita, Malin Kundang kini telah berubah menjadi seorang saudara kaya raya. Ia lantas menikahi gadis paling cantik di desa tersebut, putri dari keluarga kaya raya, (Hlm. 3, P. 5).

Peristiwa tersebut dikatakan tahap utama karena menceritakan bagaimana perjuangan tokoh utama, yaitu Malin Kundang dalam memeroleh kesuksesan dan kebahagian. Hal itu, sesuai dengan teori yang dikemukan oleh Greimas bahwa tahap utama, yaitu sang tokoh melewati masa perjuangan dengan segala tantangan.

Pada tahap kegemilangan, setelah menikahi wanita yang paling cantik di desa itu, Malin Kundang, istri, dan pengawal pergi berlayar dan mereka 
berlabuh di pantai Air Manis. Pantai Air manis adalah kampung kelahiran Malin Kundang. Kedatangan Malin Kundang diketahui Mande Rubayah. Mande Rubayah menghampiri Malin Kundang, tetapi Malin Kundang tidak mengakui Mande Rubayah sebagai Ibunya dikarena Mande Rubayah miskin dan memakai pakaian lusuh. Istri Malin Kundang sudah berusaha mengingatkan Malin Kundang, tetapi Malin Kundang tetapi bersikeras tidak mengakui kalau Mande Rubayah adalah Ibunya. Hal iti dapat dibuktikan dengan kutipan berikut ini.

Detak jantung Mande Rubayah kian cepat saat dari kejauhan ia melihat anaknya berdiri bersama seorang perempuan cantik di kapal dagang mewah tersebut, (Hlm. 4, P. 2).

Malin melepaskan pelukan ibunya dan mendorongnya dengan kasar hingga terjatuh. "Hai perempuan tua miskin tidak tahu sopan santun, Siapakah engkau? Berani-beraninya memelukku." bentak Malin pada Ibunya, (Hlm. 4, P. 4).

"Kakanda, perhatikan dahulu baikbaik apakah ibu tua itu adalah ibu kandung kakanda. Jangan langsung mengusir secara kasar begitu." Istri Malin mengingatkan suaminya, (Hlm. 4, P. 5).

Peristiwa tersebut dikatakan tahap kegemilangan karena menceritakan tentang kesejahteraan hidup tokoh utama, yaitu Malin Kundang setelah menikah dengan wanita paling cantik di desanya dan menceritakan kedatangan Malin Kundang ke pantai air manis. Di pantai air manis, istri, dan pengawal mengetahui kalau Malin Kundang memiliki ibu yang miskin, tetapi Malin Kundang tidak mengakui kalau Mande Rubayah adalah ibunya. Hal itu sesuai dengan teori yang dikemukan oleh Greimas bahwa tahap kegemilangan ditandai dengan masa kegemilangan tokoh dan sekaligus terbongkarnya jati diri tokoh yang sebenarnya.

Ketiga, situasi akhir dengan tidak diakuinya sebagai Ibu, Mande Rubayah sangat sakit hati pada Malin Kundang. Mande Rubayah merasa Malin Kundang telah menjadi anak durhaka dan Mande Rubayah mengutuk Malin Kundang menjadi batu. Tidak lama kemudian tubuhnya berubah menjadi batu dalam kondisi tengah bersujud meminta ampun pada ibunya. Oleh sebab itu, penduduk menamakan batu tersebut batu Malin Kundang. Hal tersebut dapat dibuktikan dengan kutipan berikut ini.

Kemudian Mande Rubayah
mengangkat tangannya ke atas
kemudian berdoa, "Ya Tuhan,
sekiranya lelaki yang tidak mau
mengakui hamba sebagai ibu
kandungnya dan mendorong hamba
hingga jatuh adalah benar-benar
anakku, Malin Kundang, maka aku
sumpahi ia berubah menjadi batu,
(Hlm. 4, P. 6).
Tidak lama kemudian tubuhnya
berubah menjadi batu dalam kondisi
tengah bersujud meminta ampun
pada ibunya. Malin Kundang, anak
durhaka yang malu mengakui ibu
kandungnya, kini telah menerima
azab berubah menjadi batu, (Hlm. 5,
P. 2).

Peristiwa tersebut dikatakan tahap akhir, karena tokoh utama Malin Kundang telah menerima balasan, yaitu menjadi batu dalam kondisi tengah bersujud meminta ampun pada ibunya. Hal itu sesuai dengan teori yang dikemukan oleh Greimas bahwa pada situasi kahir berkaitan dengan objek cerita akan memperoleh hukuman, balasan perbuatan yang telah dilakukan. 


\section{Analisis Struktur Fungsional Cerita Rakyat Kalimantan Selatan dengan Judul Gunung Batu Bangkai}

Pada bagian ini dijelaskan struktur fungsional cerita rakyat Kalimantan Selatan yang berjudul Gunung Batu Bangkai. Struktur fungsional yang dijelaskan merujuk pada teori Greimas yang dijelaskan sebelumnya. Ketiga struktur fungsional dalam cerita rakyat Kalimantan Selatan yang berjudul Gunung Batu Bangkai, dijelaskan sebagai berikut.

Pertama, situasi awal dalam cerita rakyat Kalimantan Selatan yang berjudul Gunung Batu Bangkai dimulai ketika Andung sebagai tokoh utama yang hanya hidup berdua dengan ibunya dan memiliki kepandaian ilmu pengobatan. Melihat hidup yang tidak kunjung berubah Andung berkeingin untuk merantau. Keingian tersebut disampaikan kepada Ibunya. Melihat kemauan keras anaknya, Ibu Andung mengizinkan Andung pergi merantau. Ibu membekali Andung dengan memberikan kalung pemberian seorang kakek yang ditolong Andung di hutan. Andungpun pergi merantau. Hal itu, dapat dibuktikan dari kutipan berikut ini.

Dahulu, di Loksado ada seorang anak bernama Andung yang tinggal berdua saja dengan ibunya yang ia panggil dengan Uma. Andung mempunyai keahlian mengobati berbagai macam penyakit. (Hlm. 1, P. 1).

Suatu saat, Andung berniat merantau mencari kehidupan yang lebih baik, (Hlm. 1, P. 6).

Berangkatlah sebelum gelap sampai di hutan. Bawalah kalung yang diberikan kakek yang kau tolong waktu itu. Ibu Andung memberikan kalung itu kepada anaknya, (Hlm. 1, P. 9).

Peristiwa tersebut dikatakan situasi awal karena menceritakan keinginan tokoh utama Andung pergi merantau untuk memperbaiki hidup dan adanya persetujuan dari Ibu atas keinginan Andung tersebut. Hal itu sesuai dengan teori yang dikemukan oleh Greimas, bahwa situasi awal berkaitan dengan munculnya pernyataan keinginan untuk mendapatkan sesuatu; adanya panggilan; adanya persetujuaan.

Kedua, tahap transformasi terdiri dari tahap kecakapan, tahap utama, dan tahap kegemilangan. Pada tahap kecakapan, Andung pergi merantau. Di rantau Andong bertemu dengan petani yang sedang sakit. Tubunya dipenuhi kudis. Andung mengobati petani tersebut sampai petani itu sembuh. Andung diminta menetap di rumah petani tersebut. Hal itu dapat dibuktikan dengan kutipan berikut ini.

Andung berangkat merantau. Ia berjalan sangat jauh, keluar masuk hutan dan lembah, melewati perkampungan-perkampungan, (Hlm. 2, P. 1).

Petani tersebut berhasil disembuhkan oleh Andung. Ia meminta Andung untuk tinggal bersamanya sebagai ungkapan rasa terima kasih. (Hlm. 2, P. 3).

Peristiwa tersebut dikatakan tahap transformasi bagian kecakapan karena menceritakan tentang awal keberangkatan tokoh Andung pergi merantau dan usaha pertama Andung di rantau mengobati petani yang sakit. Hal itu sesuai dengan teori yang dikemukan oleh Greimas, bahwa tahap kecakapan berkaitan dengan keberangkatan tokoh utama (subjek) dari tanah asal; munculnya dewa penolong; adanya lawan tanding sang tokoh.

Pada tahap utama, keberhasilan Andung mengobati petani tersebar di seluruh desa. Berita itu didengar olah Raja. Raja meminta Andung mengobati puterinya yang sedang sakit. Berkat 
bantuan kalung yang diberikan kakek yang tolong Andung di hutan puteri raja sembuh. Sebagai imbalan, Andung dinikahi dengan puteri raja tersebut. Hal itu dapat dibuktikan dengan kutipan berikut ini.

$\begin{array}{lr}\text { Keberhasilan } & \text { Andung } \\ \text { menyembuhkan banyak } & \text { orang } \\ \text { terdengar ke telinga Raja } & \text { Basiang. }\end{array}$

Sang Raja meminta Andung untuk datang ke istana untuk mengobati putrinya yang sudah beberapa minggu terbaring sakit, (Hlm. 2, P. 4).

Andung kemudian teringat kalung pemberian kakek tua yang pernah ditolongnya. Kalung tersebut direndam di dalam sebuah wadah yang sudah disediakan. Keajaiban terjadi, Sang Putri perlahan-lahan menggerakkan tubuhnyaAndung berhasil menyembuhkan putri kerajaan. Sebagai imbalan, ia menikahkan Andung dengan putrinya, (Hlm. 2, P. 6).

Peristiwa tersebut dikatakan tahap utama karena menceritakan bagaimana perjuangan tokoh utama, yaitu Andung dalam memeroleh kebahagian bisa menikahi puteri raja. Hal itu, sesuai dengan teori yang dikemukan oleh Greimas bahwa tahap utama, yaitu sang tokoh melewati masa perjuangan dengan segala tantangan.

Pada tahap kegemilangan, setelah menikah dengan puteri raja, Andung hidup sejahtera dan tidak beberapa lama puteri raja hamil dan mengidam buah katsuri. Buah katsuri hanya ada di Kalimantan. Andung berserta pangawalnya pergi ke Kalimantan untuk mencari buah katsuri. Sampai di Kalimantan, Andung menyadari kalau buah Katsuri itu hanya ada di depan rumahnya. Andung enggan bertemu dengan ibunya. Akhirnya Andung memutuskan mencari tempat lain untuk mendapatkan buak katsuri. Sebelum Andung meninggalkan Kalimantan, kabar kedatangan Andung diketahui ibu Adung. Ibu Andung menemui Andung karena Ibunya miskin Andung tidak mengakui kalau itu adalah Ibunya. Andung menghina dan mengusir Ibunya. Hal itu, dapat dibuktikan dengan kutipan berikut ini.

Kini Andung menjadi menantu Raja Basiang. Tidak lama setelah menikah, istri Andung pun hamil. Ia mengidam buah kasturi. Buah itu hanya ada di Pulau Kalimantan. Ia mengerahkan para pengawalnya untuk berangkat ke Loksado. Sesampainya di Loksado Andung menyadari bahwa pohon kasturi itu tertanam persis di depan rumah ibunya.Andung enggan bertemu dengan ibunya. Lalu, ia mengajak semua pasukannya untuk meninggalkan tempat itu dan mencari buah kasturi di tempat lain. Namun, kedatangan mereka terdengar oleh ibu yang sedang berada di dalam rumah."Andung! Andung! Anakku!"" panggil sang ibu sambil berlinang air mata. Ia sangat bahagia telah menemukan putranya kembali."Hai, nenek miskin. Kau bukan ibuku. Aku adalah keturunan bangsawan, pergi kau dari sini!" (Hlm. 3, P. 1-3).

Peristiwa tersebut dikatakan tahap kegemilangan karena peristiwa tersebut menceritakan tentang kesejahteraan hidup tokoh utama, yaitu Andung setelah menikahi anak puteri raja dan bertemunya Andung dengan Ibunya, tetapi Andung tidak mengakui kalau itu adalah ibu kandungnya. Hal itu sesuai dengan teori yang dikemukan oleh Greimas bahwa tahap kegemilangan ditandai dengan masa kegemilangan tokoh dan sekaligus terbongkarnya jati diri tokoh yang sebenarnya. 
Ketiga, situasi akhir dengan tidak diakuinya sebagai Ibu, Ibu Andung merasa sangat sedih dan pergi meninggalkan Andung. Ibu Andung merasa anaknya telah menjadi anak yang durhaka dan meminta Allah menunjukkan kekuasaan. Seketika, cuaca menjadi mendung dan hujan disertai badai yang dahsyat. Tibatiba petir menyambar tubuh Andung. Dalam sekejab, tuhubnya berubah menjadi batu. Batu tersebut menyerupai bangkai manusia. Oleh sebab itu, penduduk menamakan wilayah itu sebagai Gunung Batu Bangkai. Hal itu, dapat dibuktikan dengan kutipan berikut ini.

"Ya, Tuhan, anakku telah menjadi anak yang durhaka. Tunjukkanlah kekuasaan-Mu!" ujar Ibu Andung, (Hlm. 3, P. 4).

Tidak lama kemudian, cuaca menjadi mendung dan hujan turun disertai badai yang dahsyat. Petir menyambar tubuh Andung. Dalam sekejap, tubuhnya berubah menjadi batu. Bentuk batu tersebut seperti bangkai manusia. Akhirnya, penduduk menamakan wilayah itu sebagai Gunung Batu Bangkai, (Hlm. 3, P. 5).

Peristiwa tersebut dikatakan tahap akhir, karena tokoh utama Andung telah menerima balasan, yaitu menjadi batu berbentuk bangkai manusia karena kedurhakaanya kepada Ibunya. Hal itu sesuai dengan teori yang dikemukan oleh Greimas bahwa pada situasi kahir pada umumnya objek cerita akan memperoleh hukuman, balasan perbuatan yang telah dilakukan.

\section{Perbandingan Struktur Fungsional} Cerita Rakyat Sumatera Barat Berjudul Malin Kundang dan Kalimantan Selatan Berjudul Gunung Batu Bangkai

Pada bagian ini dijelaskan, perbandingan peristiwa yang terjadi dalam cerita rakyat Sumatera Barat yang berjudul Malin Kundang dan cerita rakyat Kalimantan Selatan yang berjudul Gunung Batu Bangkai. Perbandingan itu dianalisis berdasarkan teori struktur fungsional yang dikemukan oleh Greimas, yaitu situasi awal; transformasi yang meliputi tahap kecakapan, tahap utama, dan tahap kegemilangan; situasi akhir. Ketiga hal itu dijelaskan sebagai berikut.

Jika dilihat dari situasi awal, cerita rakyat Sumatera Barat yang berjudul Malin Kundang dan cerita rakyat Kalimantan Selatan yang berjudul Gunung Batu Bangkai memiliki persamaan dan perbedaan. Persamaan situasi awal, kedua cerita rakyat tersebut, yaitu tokoh utama (Malin Kundang dan Andung) dalam cerita rakyat tersebut sama-sama berkeingin pergi merantau dan keinginan tersebut dikabulkan oleh ibu mereka walaupun dengan berat hati. Perbedaan situasi awal dalam kedua cerita ini terletak pada banyak tokoh yang diceritakan dan bekal yang diberikan ibu. Dalam cerita rakyat Malin Kundang selain tokoh utama (Malin Kundang) dan tokoh Ibu (Mande Rubayah), di dalam cerita itu juga disebut tokoh ayah walaupun hanya di awal cerita. Akan tetapi, cerita rakyat Gunung Batu Bangkai, tidak ada tokoh ayah dalam ceritanya yang ada hanya tokoh utama (Andung) dan tokoh ibu. Selain itu, perbedaan juga terlihat dari bekal yang diberikan Ibu sebelum tokoh utama pergi merantau. Dalam cerita rakyat Malin Kundang, ibu membekali Malin Kundang dengan sedikit uang dan tujuh bungkus nasi, sedangkan dalam cerita rakyat Gunung Batu Bangkai Ibu membekali Andung kalung pemberian kakek yang ditolong Andung di hutan.

Jika dilihat dari transformasi tahap kecakapan, kedua cerita rakyat ini juga 
memiliki persamaan dan perbedaan. Persamaan transformasi tahap kecapakan dalam kedua cerita ini, yaitu kedua tokoh utama dalam cerita ini sama-sama berangkat merantau dan meninggalkan kampung halamannya. Perbedaan transformasi tahap kecapakan dalam kedua cerita ini terletak pada alat yang digunakan untuk pergi merantau dan peristiwa yang dialami selama diperjalanan. Tokoh utama dalam cerita rakyat Malin Kundang pergi merantau menumpangi kapal laut, sedangkan tokoh utama dalam cerita rakyat Gunung Batu Bangkai pergi merantau hanya dengan berjalan kaki. Selain itu, perbedaan juga dilihat dari peritiwa yang dialami selama perjalanan. Dalam perjalanan tokoh utama dalam cerita rakyat Malin Kundang kapal yang ditumpanginya dihentikan oleh bajak laut. Namun, Malin Kundang tidak sampai tertangkap. Dia terdampar di sebuah kampung dan ditolong oleh masyarat dan masyarakat mengizinkan Malin Kundang menetap di kampung tersebut. Tokoh utama dalam cerita rakyat Gunung Batu Bangkai tidak mengalami rintangan selama melakukan perjalanan. Selama melakukan perjalanan, tokoh utama (Andung) yang sering menolong masyarakat. Karena kebaikannya, Andung diminta menetap di rumah salah seorag petani yang ditolongnya.

Jika dilihat dari transformasi tahap utama, kedua cerita rakyat ini juga memiliki persamaan dan perbedaan. Persamaan transformasi tahap utama dalam kedua cerita ini, yaitu kedua tokoh utama dalam kedua cerita ini sama-sama hidup bahagia dan sejahtera serta samasama memiliki istri yang cantik. Perbedaan transformasi tahap utama dalam kedua cerita ini terletak pada usaha yang dilakukan untuk mencapai kesuksesan.
Dalam cerita rakyat Malin Kundang, kesuksesan yang diperoleh tokoh utama (Malin Kundang) dikarena kejujuran dan kerja keras dalam berdagang. Sehingga dengan kejujuran dan kerja keras tersebut tokoh utama bisa menjadi saudagar kaya raya dan bisa menikahi istri yang paling cantik di kampung tersebut. Dalam cerita rakyat Gunung Batu Bangkai, kesuksesan yang diperoleh tokoh utama (Andung) dikarena kebaikannya menolong menyumbuhkan petani-petani yang sakit. Sehingga kehebatan tokoh utama dalam menyembuhkan didengar oleh raja. Lalu, raja meminta tokoh utama mengobati puterinya yang sedang sakit. Berkat kalung yang dibekali ibunya yang merupakan pemberian kakek yang dia tolong waktu di hutan puteri raja bisa disembuhkan. Sebagai imbalan tokoh utama dinikahi dengan puteri raja tersebut.

Jika dilihat dari transformasi tahap kegemilangan, kedua cerita rakyat ini juga memiliki persamaan dan perbedaan. Persamaan transformasi tahap kegemilangan dalam kedua cerita ini, yaitu kedua tokoh utama dalam cerita ini samasama pergi ke kampung halamannya dan sama-sama menjadi anak durhaka karena tidak mengakui ibu kandung mereka. Perbedaan transformasi tahap kegemilangan dalam kedua cerita ini terletak pada tujuan tokoh utama pergi kekampungnya dan dengan siapa pergi ke kampung. Dalam cerita rakyat Malin Kundang, tokoh utama pergi ke kampung tanpa ada unsur kesengajaan, sedangkan tokoh utama dalam cerita Gunung Batu Bangkai pergi ke kampung dengan tujuan mencari buah katsuri untuk sang istri. Selain itu, perbedaan juga terlihat dari dengan siapa pergi ke kampung. Dalam cerita rakyat Malin Kundang, tokoh utama pergi ke kampung dengan dengan istri dan 
pengawalnya, sedangkan tokoh utama dalam cerita Gunung Batu Bangkai pergi ke kampung hanya dengan pengawalnya saja tanpa membawa istrinya.

Jika dilihat dari situasi akhir, kedua cerita rakyat ini juga memiliki persamaan dan perbedaan. Persamaan situasi akhir dalam kedua cerita ini, yaitu kedua tokoh sama-sama berubah menjadi batu. Hal itu disebabkan oleh kedurhakaan kedua tokoh kepada ibunya. Kedua tokoh sama-sama durhaka kepada kedua orang tunya karena kedua tokoh utama tidak mengakui ibu kandungnya lagi. Perbedaan situasi akhir kedua cerita ini terletak proses tokoh utama menjadi batu, bentuk, dan letak batunya.

Dalam cerita rakyat Malin Kundang, tokoh utama menjadi batu karena dikutuk sendiri oleh Ibu kandungnya disebabkan oleh kedurhakaan sendiri. Tokoh utama dalam cerita Gunung Batu Bangkai menjadi batu dikarenakan azab yang diberikan oleh Allah karena kedurhakaan tokoh utama kepada ibunya. Dalam cerita rakyat Gunung Batu Bangkai, ibu tokoh utama tidak mengutak tokoh utama tetapi Allahlah yang memberikan azab tersebut.

Perbedaan kedua cerita tersebut juga bisa dilihat dari bentu dan letak batunya. Dalam cerita rakyat Malin Kundang, bentuk batu tokoh utama menyerupai orang yang sedang bersujut memohon ampun kepadanya ibunya dan batu tersebut berada di tepi pantai. Dalam cerita rakyat Gunung Batu Bangkat, bentuk batu tokoh utama menyerupai bangkai dan terletak di gunung. Agar lebih jelas perbedaan struktur fungsional cerita rakyat dari Sumatera Barat yang berjudul Malin Kundang dan cerita rakyat dari Kalimantan Selatan yang berjudul Gunung Batu Bangkai dapat dilihat pada tabel 3 di bawah ini.
Tabel 3. Perbedaan Struktur Fungsional Cerita Rakyat Malin Kundandan Cerita Rakyat Gunung Batu Bangkai

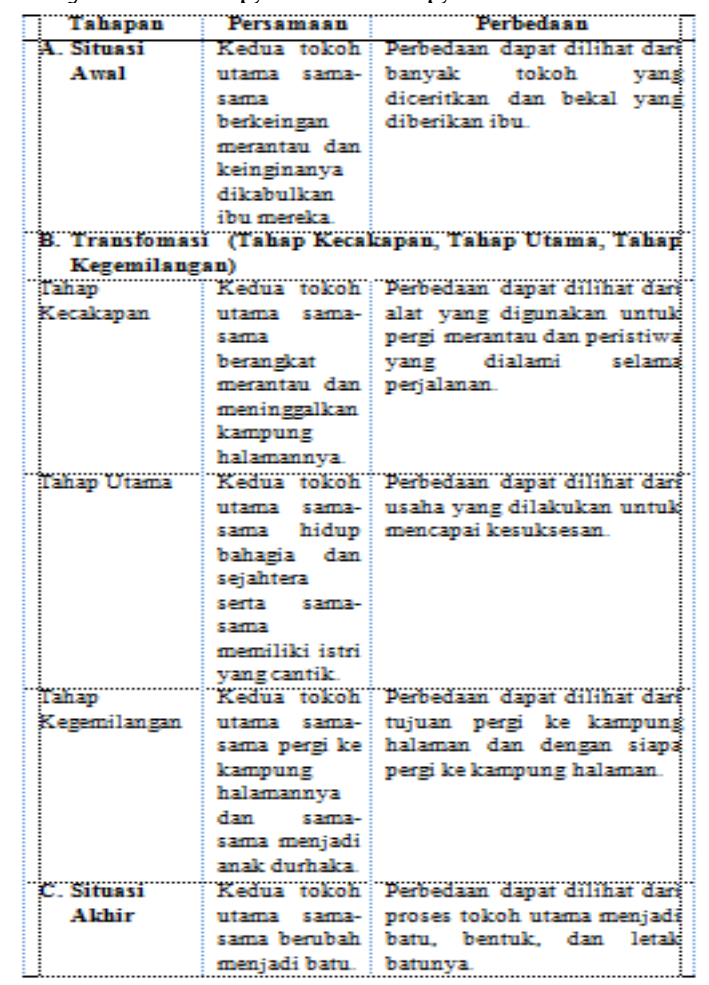

\section{Simpulan}

Berdasarkan hasil penelitian dan pembahasan, simpulan penelitian ini yaitu sebagai berikut. (1) Struktur fungsional cerita rakyat Sumatera Barat yang berjudul Malin Kundang, dianalisis dari situasi awal; tahap transformasi yang terdiri dari tahap kecakapan, tahap utama, dan tahap kegemilangan; dan tahap akhir. Analisis itu merujuk pada teori yang dikemukan oleh Greimas. (a) situasi awal menceritakan tentang tokoh utama Malin Kundang hidup berdua dengan Ibunya, yaitu Mande Rubayah setelah kepergian ayahnya merantau. Melihat kehidupan yang tidak kunjung berubah, Malin Kundang ingin merantau. Dengan berat hati, Mande Rubayah mengizinkan Malin Kundang merantau. (b) transformasi tahap kecakapan menceritakan tentang Malin Kundang pergi merantau menumpangi kapal yang berlabuh di kampungnya. Diperjalanan kapal yang ditumpanginya 
dihentikan bajak laut. Malin Kundang selamat dan terdampar di sebuah kampung. Warga menolong Malin Kundang dan mengizinkan Malin Kundang tinggal di kampung tersebut. Transformasi tahap utama, menceritakan tentang pekerjaan Malin Kundang di rantau, yaitu berdagang. Berkata kejujuran dan kerja kerasnya dia berhasil menjadi saudagar kaya raya. Karena kekayaanya Malin Kundang berhasil menikahi wanita paling cantik di kampung tersebut. Transformasi tahap kegemilangan menceritaan setelah menikah kehidupan Malin Kundang semakin bahagia. Tanpa sengaja dia pergi berlayar dan berlabuh di kampung halamannya. Sesampai di Kampung, Malin Kundang tidak mengakui Mande Rubayah sebagai ibunya. Walaupun sudah diingatkan oleh istri, Malin Kundang tetap tidak mengakuinya, bahkan mengatakan Mande Rubayah seorang pengemis yang mengaku sebagai ibunya. (c) situasi akhir menceritakan tentang Mande Rubayah sakit hati atas perlakukan Malin Kundang. Mande Rubayah mengutuk Malin Kundang menjadi batu. Seketika itu, badai datang tiba-tiba lalu menghantam kapal dagang milik Malin Kundang. Kapal Malin Kundang hancur berkeping-keping. Tubuh Malin Kundang berubah menjadi batu dalam kondisi tengah bersujud meminta ampun pada Mande Rubayah.

(2) Struktur fungsional cerita rakyat Kalimantan Selatan yang berjudul Gunung Batu Bangkai dianalisis dari situasi awal, tahap transformasi yang terdiri dari tahap kecakapan, tahap utama, dan tahap kegemilangan, dan tahap akhir. Analisis itu merujuk pada teori yang dikemukan oleh Greimas. (a) situasi awal menceritakan tentang tokoh utama Andung hidup berdua dengan Ibunya. Melihat kehidupan yang tidak kunjung sejahtera, Andung berkeinginan untuk merantau agar memperoleh kehidupan yang lebih baik lagi. Ibu mengizinkan Andung merantau. (b) transformasi tahap kecakapan menceritakan tentang tokoh utama, Andung pergi merantau. Di perjalanan, Andung menolong mengobati petani yang sakit. Andung diminta menetap di rumah petani itu. Transformasi tahap utama menceritakan tentang keberhasilann Andung menyembuhkan petani didengar oleh raja. Lalu raja meminta Andung menyembuhkan puterinya. Andung bisa menyembuhkan puteri raja. Sebagai imbalan Andung dinikahi dengan puteri raja tersebut. Transformasi tahap kegemilangan menceritakan, setelah menikah dengan puteri raja, Andung hidup bahagia dan puteri raja hamil dan mengidam buah katsuri. Andung dan pengawal pergi ke Kalimantan mencari buah katsuri. Sampai di Kalimantan, Andung bertemu ibunya dan dia tidak mengakui Ibu Kandungnya. Andung malah menghina dan menguri ibunya. (c) situasi akhir menceritkan tentang ibu Andung merasa sangat kecewa dengan tidak diakuinya dia sebagai Ibu oleh Andung. Lalu, ibu berdoa kepada Allah agar Andung mendapat hukuman atas kedurhakaannya. Seketika, cuaca menjadi mendung dan hujan disertai badai yang dahsyat. Tiba-tiba petir menyambar tubuh Andung. Dalam sekejab, tuhubnya berubah menjadi batu. Batu tersebut menyerupai bangkai manusia.

(3) Perbandingan cerita rakyat Sumatera Barat dengan Judul Malin Kundang dan cerira rakyat Kalimantan Selatan dengan judul Gunung Batu Bangkai dilihat dari situasi awal, transformasi, dan situasi akhir yang dikemukan oleh Greimas. (a) situasi awal, 
kedua cerita rakyat tersebut memiliki persamaan, tokoh utama sama-sama berkeinginan merantau. Perbedaan dilihat dari jumlah tokoh dan bekal merantau yang diberikan. (b) transformasi kedua cerita rakyat tersebut memiliki persamaa, tokoh utama sama-sama berangkat merantau; hidup bahagia dan istri cantik; menjadi anak durhaka. Perbedaannya dilihat dari alat digunakan untuk merantau; peristiwa yang dialami diperjalanan; usaha yang dilakukan mencapai kesuksesan. (c) situasi akhir kedua cerita rakyat tersebut memiliki persamaa, sama-sama berubah menjadi batu. Perbedaannya, dilihat dari proses tokoh utama menjadi batu, bentuk, dan letak batunya.

\section{Daftar Pustaka}

Ariningsih, N. E. (2012). "Analisis Kesalahan Berbahasa Indonesia dalam karangan Eksposisi Siswa Menengah Atas". Forum Penelitian 1 (1): 41-42.

Atmazaki. (2007). Kiat-Kiat Mengarang dan Menyunting. Padang: UNP Press.

Basri. (2010). Prosiding Seminar nasional Bahasa, Satra, dan Pembelajarannya. Padang: Sukabina Pres.

Basrowi dan Suwandi. (2008). Memahami Penelitian Kualitatif. Jakarta: PT Asdi Mahasatya.

Brown, H. D. (2007). Principles Of Language Learning and Teaching. Amerika: Perason Education.

Chaer, A.(2009). Psikolinguistik: Kajian Teoritik. Jakarta: Rineka Cipta.
Ellis, R. (1995). The Study Of Second LanguangeAcquasition. New York: Oxford University Press.

Ghufron, S. (2009). Peranti Kohesi dalam Wacana Tulisan Siswa: Perkembangan dan Kesalahan”. Forum penelitian 40 (1): 82.

Jalal, M. (2012). "Problematika Kesalahan Bahasa Pada Penulisan Skripsi Mahasiswa Universitas Airlangga”. Forum Penelitian 12 (2) 92 .

Manaf, N. A. (2010). Sintaksis Teori dan Terapannya dalam Bahasa Indonesia. Padang: Sukabina Press.

Mara'at, S.(2009). Psikolinguistik. Bandung: PT Refika Aditama.

Mardalis. (2009). Metode Penelitian Pendekatan Proposal. Jakarta: Bumi Aksara.

Putrayasa, I. B. (2010). Kalimat Efektif (Diksi, Sruktur, dan Logika). Bandung: PT Refika Aditama.

Rofi'uddin, A. (2003). Rancangan Penelitian Pengajaran Bahasa Indonesia. Malang: Universitas Negeri Malang.

Sumadi. (2009). "Kalimat Bahasa Indonesia dalam Wacana Tulis Siswa Kekas VI SD”. Forum Penelitian 37 (1): 32.

Tarigan, H. G. (1988). Pengajaran Pemerolehan Bahasa. Jakarta: Departemen Pendidikan dan Kebudayaan. 
Tarigan, dan Lilis, S. S. (1997). Analisis Kesalahan Berbahasa. Jakarta: Departemen Pendidikan dan Kebudayaan.
Wibowo, W. (2009). Menjadi Penulis \& Penyunting Sukses: Langkah Jitu Merangkai Kata Agar Komunikatif, Hidup, dan Memikat. Jakarta: Bumi Aksara. 